\title{
Characterization of Rice Blast Resistance Gene Pi61(t) in Rice Germplasm
}

Jianbing Ma, Rice Research and Extension Center, University of Arkansas, Stuttgart 72160; and M. H. Jia and Y. Jia, United States Department of Agriculture-Agricultural Research Service, Dale Bumpers National Rice Research Center, Stuttgart, AR 72160

\begin{abstract}
Ma, J., Jia, M. H., and Jia, Y. 2014. Characterization of rice blast resistance gene Pi61(t) in rice germplasm. Plant Dis. 98:1200-1204.

Identification of resistance $(R)$ genes to races of Magnaporthe oryzae in rice (Oryza sativa) germplasm is essential for the development of rice cultivars with long-lasting blast resistance. In the present study, one major quantitative trait locus, qPi93-3, was fine mapped using a recombinant inbred line (RIL), $\mathrm{F}_{8}$ RIL171, derived from the cross between 'Nipponbare' and '93-11'. RIL171 contained a heterozygous qPi93-3 allele which was found to be resistant against nine U.S. common races-ID1, IA1, IB49, IE1, IA45, IB1, IC17, IB45, and IH1-of M. oryzae. An $\mathrm{F}_{2}$ mapping population consisting of 2,381 individuals derived from RIL171was evaluated with a field isolate (race) ARB82 (IA1) of $M$. oryzae under greenhouse conditions. Disease reaction of a

resistant/susceptible ratio of 3:1 was identified with $\mathrm{F}_{2}: \mathrm{F}_{3}$ families. In total, 12 simple sequence repeat markers spanning $q P i 93-3$ were used for fine mapping. Consequently, $q P i 93-3$ was delimited to $4.2 \mathrm{Mb}$ between RM3246 and RM7102. Three insertion-deletion (InDel) markers located between RM3246 and RM7102, that had previously used to map Pi61(t), showed that qPi93-3 was Pi61(t). The existence of $P i 61(t)$ in 136 rice germplasm lines from the United States Department of Agriculture rice core collection was evaluated using Pi61(t)-specific InDel markers. Pi61 $(t)$ was identified as a source of resistance in 5 of the 136 lines. The characterized germplasm will be useful for rice breeders to use for improving blast resistance.
\end{abstract}

Rice blast, caused by the filamentous fungal pathogen Magnaporthe oryzae, is one of the most devastating diseases that reduces rice yield around the world. Reliance on host resistance $(R)$ is the most economical and environmentally friendly strategy to control rice blast. After the first blast $R$ gene, Pia, was identified in 1967 (14), about 100 blast $R$ genes have been mapped on rice chromosomes $(1,22)$. Blast $R$ genes were found in all chromosomes except chromosome 3 , and some of them are clustered (i.e., chromosomes 6, 11, and 12) $(1,18,22)$. However, major $R$ genes are often rapidly overcome by new virulent $M$. oryzae isolates. Efforts have been made worldwide to identify a broad spectrum of resistance to blast $(3,18)$.

In many crops, the majority of traits are regulated by multiple genes rather than a single gene. These multiple genes, each with a relatively minor effect, are referred to as quantitative trait loci (QTLs; 4). Identification and mapping QTLs is an important strategy to discover blast $R$ genes. Up to now, about 350 QTLs for blast resistance have been identified, and a few have been validated (1). In addition, 23 blast resistance genes have been mapped on rice chromosomes within identified QTL regions (22).

DNA markers tightly linked to known $R$ genes are vital for breeding via a marker-assisted selection (MAS) approach. Pik-m and $P i k$ were differentiated by allele-specific DNA markers (2), while $P i-z$ and $P i-b$ were identified in rice germplasm from United States Department of Agriculture (USDA) core collections using simple sequence repeat (SSR) markers or Pib-dominant markers $(5,20,21,26)$. The presence of $P i-b$ and $P i$-ta in 42 indica-type varieties from the International Rice Research Institute in the Phil-

Corresponding author: Y. Jia, E-mail: yulin.jia@ ars.usda.gov

The United States Department of Agriculture is an equal opportunity provider and employer.

* The $e$-Xtra logo stands for "electronic extra" and indicates that two supplementary tables are available online.

Accepted for publication 24 February 2014.

http://dx.doi.org/10.1094/PDIS-09-13-1014-RE

This article is in the public domain and not copyrightable. It may be freely reprinted with customary crediting of the source. The American Phytopathological Society, 2014. ippines were investigated using polymerase chain reaction (PCR)based dominant markers $(6,12,26)$. Moreover, single-nucleotide polymorphism markers identified six $R$ genes (Piz, Piz-t, Pik, Pik$m$, Pik-p, and $P i t$ ) in aromatic rice accessions (13).

$P i$-ta is an important blast $R$ gene that initially was introduced to the United States from landrace indica varieties 'Tetep' and 'Tadukan'. It confers resistance to the major blast races (isolates) in the United States (11). The Pi-ta gene was identified in the USDA core collection by a designed Pi-ta insertion-deletion (InDel) marker $(12,25)$. The presence of $P i-t a$ was verified in 89 rice accessions using various DNA markers and also by disease reactions of $M$. oryzae to races IB49 and IE1K (25). These results illustrated that DNA markers linked to $R$ genes were useful for detecting the function of $R$ genes and, thus, could be widely used in rice improvement programs utilizing MAS.

Cultivated rice, Oryza sativa L., has two major subspecies, japonica and indica. Genomes of both 'Nipponbare' (japonica) and '93-11' (indica) have been sequenced $(9,31)$ and, thus, there is fundamental genomic information available to investigate blast $R$ genes. Nipponbare contains two $R$ genes, Pish and Pia, on chromosome 1 (8) and 11 (28), respectively. Moderate resistance of Nipponbare to $M$. oryzae race PO6-6 has been reported (23). Rice 9311 is resistant to the major Chinese $M$. oryzae isolates and contains three blast $R$ genes: Pi41, Pi60(t), and Pi61(t) (17,30).

Four major QTLs for resistance to six isolates of $M$. oryzae were reported in a recombinant inbred line (RIL) population, containing $259 \mathrm{~F}_{7}$ RILs, which was developed from a cross of Nipponbare and 93-11 (29). Three of these genes- $q P i 93-1, q P i 93-2$, and $q P i 93-$ 3 -originated from the resistant donor 93-11, and qPi93-3 was linked to SSR marker RM7102 on chromosome 12. In all, 16, 53, and $28 \%$ of the phenotypic variation in resistance to isolates CHE 86, ARB52 (IA1), and ARB94, respectively, was explained (29). In addition, the $R$ gene $P i 61(t)$ was mapped to a $200-\mathrm{kb}$ region on chromosome 12 using an $\mathrm{F}_{2}$ population derived from a cross between susceptible japonica 'Lijiangxintuanheigu' (LTH) and resistant 93-11 (17). The Pi61(t) gene co-segregated with InDel marker M9 and was flanked by InDel markers M2 and S29 (17).

The objectives of this study were to (i) fine map the blast resistant QTL, qPi93-3, on chromosome 12, using $\mathrm{F}_{2: 3}$ progeny families of RIL171; (ii) determine the resistance spectrum of RIL171 to 14 commonly occurring races of $M$. oryzae in the United States; and (iii) analyze resistance genes in rice germplasm collections. 


\section{Materials and Methods}

Selection of plant materials, growth. In all, 259 RILs derived from Nipponbare $\times$ 93-11 were developed at the USDA Agricultural Research Service Dale Bumpers National Research Center, Stuttgart, AR (G. Wang and Y. Jia, unpublished data). One RIL, $\mathrm{F}_{8}$ RIL171, which contained a heterozygous $q P i 93-3$ allele, was selected for fine mapping. In total, 2,381 $\mathrm{F}_{2}$ individuals, derived from RIL171, were sown in plastic trays with 96 wells per tray. Ten seeds each of Nipponbare and 93-11 were also planted as parental checks. The trays were completely filled with water and placed in the greenhouse. When the seedlings reached three- to four-leaf stage, they were used for pathogenicity assays and samples were collected for DNA extraction. In addition, the presence of Pi-ta in a total of 89 accessions from the 183 USDA rice core collection lines that contained the Pi-ta InDel marker associated with the presence of $P i$ - $t a$ based on previous study (25) was verified. Furthermore, 136 accessions from the core collection were used for an $R$ gene survey.

Pathogenicity assay. The field isolate (race) ARB82 (IA1) of $M$. oryzae (previously named ARB52 [IA1[), virulent to Nipponbare but avirulent to 93-11, was selected for pathogenicity assays. Plants were inoculated with the pathogen using a modified procedure according to Valent et al. (24). Briefly, each tray was initially placed in a clear polyethylene autoclave bag, then sprayed with 30 $\mathrm{ml}$ of spore suspension (4 to $5 \times 10^{5}$ spores $/ \mathrm{ml}, 0.25 \%$ gelatin) using an airbrush connected to an air compressor. Inoculated seedlings were maintained at approximately $98 \%$ relative humidity at room temperature $\left(21^{\circ} \mathrm{C}\right)$. After $24 \mathrm{~h}$, inoculated seedlings were moved to the greenhouse and blast disease was scored 7 days post inoculation based on a rating scale described by RoyChowdhury et al. (20). This scale is based on the lesion size and the percentage of the total leaf area that has lesions and is defined as $0=$ no lesion formation, 1 = lesions restricted at the infection sites or covering $5 \%$ of total leaf area, $2=$ restricted spindle lesions with diameter $<2 \mathrm{~mm}$ or covering 5 to $10 \%$ of the total leaf area, $3=$ lesions merge to form eye-shaped brown areas with diameter $>2 \mathrm{~mm}, 4=$ lesions cover more than $50 \%$ of the total leaf area, and $5=$ lesions cover more than $70 \%$ of the total leaf area. Disease ratings of 0 to 2 are rated resistant and ratings of 3 to 5 are susceptible.

To determine the resistance spectrum of RIL171, 14 races (isolates) of $M$. oryzae that are common in the United StatesIG1(ZN39), IB33(FL9), ID1(ZN42), IA1(ARB82), IB49(ZN61), IB54, IE1K(TM2), IC1(ARB86), IE1(ZN13), IA45(75L14), IB1, IC17(ZN60), IB45, and IH1-were used to test disease reactions of Nipponbare, 93-11, and RIL171. Ten seeds of each (parent Nipponbare, 93-11, and RIL171) were planted in individual pots with holes at the bottom. All the pots were placed in trays filled with water. These experiments were repeated at three different times.

DNA extraction. Two methods were used to extract DNA. The rapid DNA extraction method described by Xin et al. (27) was used for DNA preparation for analysis of the $\mathrm{F}_{2}$ population. For additional marker analysis, large quantities of DNA from selected rice recombinants were extracted following the cetyltrimethylammonium bromide method described by Hulbert and Bennetzen (19).

Marker selection and analysis. Two sets of SSR makers were used to construct a linkage map. One set, developed by McCouch et al. (19), was used to screen the entire population and included five SSR makers: RM6998, RM7003, RM3246, RM7102, and RM519 (Table 1). The marker interval for $q$ Pi93-3 occurred between SSR markers RM3246 and RM7102 (29). After recombinants were identified, a second set of SSR markers-OSM89, RM27940, RM27941, XW137/138, XW249/250, XW121/122, and RM1261-were used to define the resistant region. Three SSR markers-XW137/138, XW249/250, and XW121/122 - were then designed based on the sequence of Nipponbare. (http://www. gramene.org/Oryza_sativa/) (Table 1). The genetic map was constructed based on MapDisto software (MapDisto. v. 1.7.7).

The PCR mixture contained $10 \mathrm{mM}$ Tris- $\mathrm{HCl}(\mathrm{pH} 8.3), 50 \mathrm{mM}$ $\mathrm{KCl}, 2.5 \mathrm{mM} \mathrm{MgCl} 2,300 \mathrm{nM}$ each primer, and 1 unit of Taq DNA polymerase (Promega Corp.) with $20 \mathrm{ng}$ of template DNA in a total of $25 \mu \mathrm{l}$. For each SSR marker, the forward primer was labeled with fluorescent dyes 6FAM, NED, and Hex from Applied Biosystems or Integrated DNA Technologies. Reverse primers were unlabeled. PCR amplification were performed using MJ Research Tetrad thermocyclers under the following conditions: (i) initial denaturation at $94^{\circ} \mathrm{C}$ for $5 \mathrm{~min}$; (ii) 35 cycles of $94^{\circ} \mathrm{C}$ for $1 \mathrm{~min}, 55$ to $61^{\circ} \mathrm{C}$ for $1 \mathrm{~min}$, and $72^{\circ} \mathrm{C}$ for $2 \mathrm{~min}$; and (iii) $5 \mathrm{~min}$ of final extension at $72^{\circ} \mathrm{C}$. Two or three PCR products were combined based on the color and size of amplified PCR products following the manufacturer's instructions. PCR products were diluted between 50 and 500 times, and $2 \mu$ of the diluted PCR products were added to $9 \mu \mathrm{l}$ of formamide containing the LIZ-labeled size standard (Applied Biosystems). The PCR products were run on an ABI 3730 DNA Analyzer according to the manufacturer's protocol (Applied Biosystems). Amplified fragment sizing and SSR marker genotype were analyzed using Gene Mapper software (version 3.7; Life Technologies Corp.).

Three InDel makers-M2, M9, and S29 (17; Table 1)-also were used for analyses of the selected recombinants and the 136 rice germplasm collections. The PCR conditions were the same as previously described, and gene-specific PCR products were separated on $3.0 \%$ agarose gels. Gels were stained with $10 \%$ SYBR

Table 1. Sequence information of simple sequence repeat (SSR) and insertion-deletion (InDel) markers used for fine mapping the Pi61(t)gene ${ }^{\mathrm{a}}$

\begin{tabular}{|c|c|c|c|c|c|c|}
\hline \multirow[b]{2}{*}{ Marker } & \multirow[b]{2}{*}{ Forward primer $\left(5^{\prime}-3^{\prime}\right)$} & \multirow[b]{2}{*}{ Reverse primer $\left(5^{\prime}-3^{\prime}\right)$} & \multicolumn{2}{|c|}{ Physical position (bp) } & \multirow[b]{2}{*}{ Size $(\mathbf{b p})^{\mathbf{b}}$} & \multirow[b]{2}{*}{$\mathbf{T}\left({ }^{\circ} \mathbf{C}\right)^{\mathbf{c}}$} \\
\hline & & & Start & End & & \\
\hline RM6998 & AGATGATAAGCTTGCGGACC & ATGCAGATGAGTCCCTCCAC & $4,745,091$ & $4,745,301$ & 210 & 55 \\
\hline RM7003 & GGCAGACATACAGCTTATAGGC & TGCAAATGAACCCCTCTAGC & $6,775,083$ & $6,775,183$ & 100 & 55 \\
\hline OSM89 & TTGGTCAAAGTTAGCCATGGGAGGG & TTTGAACCGGGTGGCCCACATG & $8,826,555$ & $8,826,854$ & 299 & 67 \\
\hline RM3246 & GCCACTCATATAAGCAAATG & TGGTTAATGGTCAGAACCTG & $9,092,467$ & $9,092,762$ & 295 & 55 \\
\hline M2 & GGCAGAGCGAGTGCTTGTCGAG & TGCCCAGACAGTTGGATTGGACA & $9,925,293$ & $9,924,675$ & 662 & 58 \\
\hline M9 & CGATTTTCCTTCTCACCTGGGGG & TGGCCTATGGCTGCTGGAAGT & $9,985,472$ & $9,984,645$ & 880 & 58 \\
\hline S29 & CATCTCCCCCTAGTCGCTCT & AGCAACAGGAACCAAACACC & $10,124,186$ & $10,124,419$ & 234 & 60 \\
\hline XW137F/XW138R & ATCCTTTCATCTGTGTTGGCCC & TACGCACCTTCCTATCGCTCTT & $10,124,634$ & $10,124,946$ & 312 & 55 \\
\hline XW249F/XW250R & AAGTTGTGTGTCGCTTGCTG & TCTGCTTTGAAGTTGGCA & $10,739,366$ & $10,739,473$ & 107 & 55 \\
\hline XW121F/XW122R & CGACAGGAAAAACTTGTTAGGAA & AGTTGTGTGTCGCTTGCTGT & $10,739,382$ & $10,739,491$ & 109 & 55 \\
\hline RM27940 & CGAAGGCTATCTTATCTCCCGAACC & AAGAAGATCACGCCCGAGGTAGG & $10,760,041$ & $10,760,144$ & 103 & 55 \\
\hline RM27941 & GCTGTTTCGATGCGTATTTCTGC & GCGTGAATCTAACCGAGAAACG & $10,768,383$ & $10,768,568$ & 185 & 55 \\
\hline RM7102 & TTGAGAGCGTTTTTAGGATG & TCGGTTTACTTGGTTACTCG & $13,211,325$ & $13,211,536$ & 211 & 55 \\
\hline RM1261 & GTCCATGCCCAAGACACAAC & GTTACATCATGGGTGACCCC & $17,531,111$ & $17,531,328$ & 217 & 55 \\
\hline RM519 & AGAGAGCCCCTAAATTTCCG & AGGTACGCTCACCTGTGGAC & $19,903,791$ & $19,903,912$ & 121 & 55 \\
\hline
\end{tabular}

a SSR markers included RM6998, RM7003, OSM89, RM3246, XW137F/XW138R, XW249F/XW250R, XW121F/XW122R, RM27940, RM27941, RM7102, RM1261, and RM519. InDel markers included M2, M9, and S29 (17).

b Expected size.

c Annealing temperature. 
Safe DNA gel Stain (Invitrogen) for visualizing the sizes of PCR products.

\section{Results}

Broad-spectrum resistance found in RIL171. Parents Nipponbare and 93-11, and RIL171, exhibited differential disease reactions to 14 common blast races of $M$. oryzae in the United States (Table 2). Nipponbare was susceptible to all $14 M$. oryzae races. However, 93-11 was resistant to most $M$. oryzae races (78.6\%), except for IB33 (FL9), IB54, and IE1K (TM2). RIL171 was resistant to nine races of $M$. oryzae (64.3\%) and susceptible to IG1 (ZN39), IB33 (FL9), IB54, IE1K (TM2), and IC1 (ARB86).

Identification of a major blast $\boldsymbol{R}$ gene in RIL171. Among all $\mathrm{F}_{2}$ RIL171 progeny, 1,723 individuals were resistant and 658 were susceptible to IA1 (ARB82). The segregation of resistant/ susceptible fitted a 3:1 ratio $\left(\chi^{2}=8.820, P<0.01\right)$, indicating that RIL171 carries a single dominant $R$ gene. Because the locus qPi93-3 was previously mapped between RM3246 and RM7102 (29), five SSR markers at the qPi93-3 locus were used for recombinant tests (Fig. 1A). In all, 63 recombinants were selected and an additional 7 polymorphic SSR markers were used for fine mapping (Fig. 1A). The $R$ gene was located within $4.1 \mathrm{Mb}$ between RM3246 and RM7102.

Three InDel markers-M2, M9, and S29 (17)—were used to determine whether the $R$ gene to ARB82 (IA1) of $M$. oryzae in RIL171 was Pi61(t). The data results indicated that M2 and S29 were co-dominant markers for Nipponbare and 93-11 and flanked Pi61(t), while M9 was a dominant maker for Nipponbare and cosegregated with Pi61(t) (Fig. 2). The allele sizes of M2, M9, and S29 for Nipponbare were 620, 850, and 250 nucleotides (nt), respectively, and the alleles sizes of M2 and S29 for 93-11 were 150 and $220 \mathrm{nt}$, respectively (Fig. 2). All 35 resistant recombinants were predicted to have 93-11 alleles for all three InDel markers (Supplementary Table $\mathrm{S} 1$ ), suggesting that the $R$ gene in RIL171 is $P i 61(t)$, which was about $200 \mathrm{~kb}$ between 9.93 and $10.12 \mathrm{Mb}$ on chromosome 12 (Fig. 1B).
Analysis of Pi61(t) in rice germplasm. The Pi61(t)-specific markers M2, M9, and S29 were used to survey 136 rice germplasm collections. The 93-11 allele was not found in 125 rice germplasm collections, suggesting that these collections lack Pi61( $t$ ) (Supplementary Table S2). However, the M2 93-11 allele was found in 11 rice germplasm collections (Table 3). Five of these germplasms (P881-12-4-B, Ai Chueh Li, 519, SL 22-613, and Gazi) were resistant to IA1, suggesting that they contain Pi61(t). The remaining accessions (Esperanza, Laat, D 6-2-2, Gaza, Shima, and WB 103) were susceptible to IA1, suggesting that they do not carry $\operatorname{Pi61}(t)$.

\section{Discussion}

In the present study, the previously identified major QTL, qPi93-3 (30), in 93-11 was determined to be a major $R$ gene in RIL171, a progeny derived from the cross of Nipponbare with 9311. The $q P i 93-3$ allele was delimited to a $4.1-\mathrm{Mb}$ region between RM3246 (9.1 Mb) and RM7102 (13.2 Mb), whereas the Pi61 $(t)$ was located at 9.92 to $10.12 \mathrm{Mb}$ on chromosome 12 (17). We analyzed $2,381 \quad \mathrm{~F}_{2}$ individuals and were unable to identify recombinants between RM3246 and RM7102 due to reduced recombination (10). Using DNA markers and pathogenicity assays, we determined that $q P i 93-3$ is $P i 61(t)$, a major gene resistant to prevalent Chinese isolates of M. oryzae (17). After testing M2, M9, and $\mathrm{S} 29$ in the selected 63 key recombinants from $2,381 \mathrm{~F}_{2}$ individuals, the results indicated resistance co-segregated with 93-11 alleles while the susceptibility co-segregated with Nipponbare alleles, suggesting that $q P i 93-3$ is $P i 61(t)$. Another $R$ gene, $P i 58(t)$, was located within $3.8 \mathrm{Mb}$ between 7.46 and $11.26 \mathrm{Mb}$, flanked by SSR markers RM6905 and RM27954 and co-segregated with SSR markers RM3103 and RM27933 (16). The genomic region of Pi61(t) was delimited within $P i 58(t)$. It remains to be determined whether $\operatorname{Pi61}(t)$ is an allele of Pi58(t). Nevertheless, there were five nucleotide-binding site leucine-rich repeat (NBS-LRR) proteins between 9.92 and $10.12 \mathrm{Mb}$; four of which were amplified in 93-11 (17). Further analysis of these NBS-LRR genes will help to identify superior DNA markers and, eventually, allow cloning of Pi61(t).

Table 2. Disease reactions of RIL171, Nipponbare, and 93-11 to 14 common races (isolates) of Magnaporthe oryzae in the United States ${ }^{\mathrm{a}}$

\begin{tabular}{|c|c|c|c|c|c|c|c|c|c|c|c|c|c|c|}
\hline \multirow[b]{2}{*}{ Cultivar or line } & \multicolumn{14}{|c|}{ Blast races } \\
\hline & IG1 & IB33 & ID1 & IA1 & IB49 & IB54 & IE1K & IC1 & IE1 & IA45 & IB1 & IC17 & IB45 & IH1 \\
\hline RIL171 & S 4 & S 3 & R 2 & R 2 & R 2 & S 3 & S 3 & S 4 & R 1 & R 2 & R 2 & R 1 & R 2 & R 1 \\
\hline Nipponbare & S 4 & S 3 & S 3 & S 5 & S 4 & S 3 & S 3 & S 3 & S 3 & S 3 & S 3 & S 3 & S 3 & S 3 \\
\hline $93-11$ & R 0 & S 4 & R 0 & R 0 & R 0 & S 3 & S 3 & R 0 & R 2 & R 0 & R 0 & R 0 & R 0 & R 0 \\
\hline
\end{tabular}

${ }^{a}$ Disease reactions: 0 to $2=$ resistant (R) and 3 to $5=$ susceptible (S). Common races (isolates) were IG1(ZN39), IB33(FL9), ID1(ZN42), IA1(ARB82), IB49(ZN61), IB54 (unnamed), IE1K(TM2), IC1(ARB86), IE1(ZN13), IA45(75L14), IB1(unnamed), IC17(ZN60), IB45(unnamed), and IH1(unnamed).

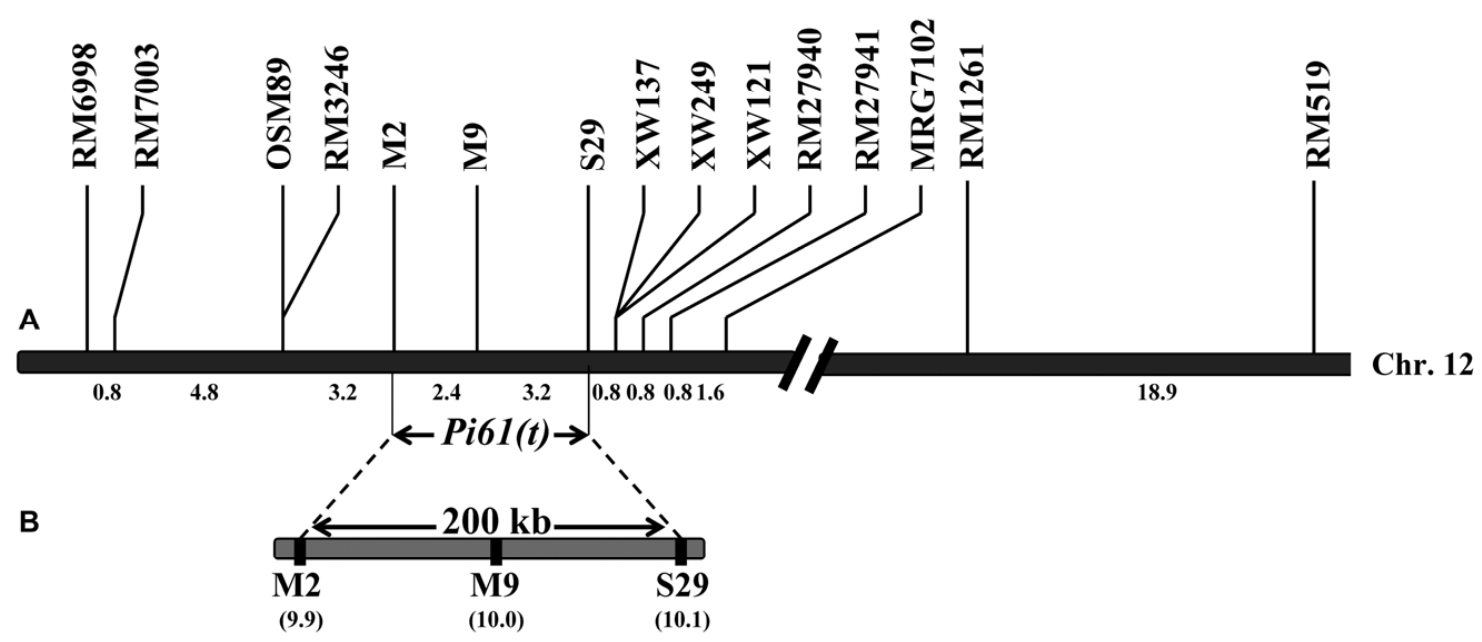

Fig. 1. Genetic and physical map of $P i 61(t)$ with simple sequence repeat (SSR) and insertion-deletion (InDel) markers. A, Genetic map of $P i 61(t)$, unit for numbers below the line is centimorgan (cM); Pi61(t) was fine mapped within $200 \mathrm{~kb}$ flanked by InDel markers M2 and S29 and co-segregated with M9. SSR markers RM6998, RM7003, RM3246, RM7102, and RM519 were used to screen for recombinants; SSR markers OSM89, RM27940, RM27941, XW137/138, XW249/250, XW121/122, and RM1261, were used to define the resistant region. B, Numbers below markers were physical distances with the unit of megabases (Mb). 
Historically, genetic resistance to different pathogens or different races of the same pathogen has been mapped within a small genetic interval. Rice varieties carrying Pi58(t) were resistant to 17 of 20 standard blast races or isolates $(15,16)$. Similarly, 93-11 rice carrying Pi61( $t$ ) was resistant to 9 of 14 U.S. common races of $M$. oryzae: ID1(ZN42), IA1(ARB82), IB49(ZN61), IE1(ZN13), IA45(75L14), IB1, IC17(ZN60), IB45, and IH1. Another blast $R$ gene, $P i$-ta , was predicted to prevent infections by nine U.S. blast races (isolates): IA45(75L14), IB1, IB45, IB49(ZN61), IC17(ZN60), IG1(ZN39), ID1(ZN42), IE1(ZN13), and IH1 (11). Consequently this gene has been widely used for breeding tropical japonica blast-resistant cultivars in the southern United States (10). The physical location of Pi-ta is between 10.60 and $10.61 \mathrm{Mb}$ on chromosome 12. These findings suggest that there is a cluster of blast $R$ genes-Pi-ta, Pi36(t), Pi58(t), and Pi61(t)—providing resistance to different races or isolates of $M$. oryzae in the central region of chromosome 12 .

In summary, based on the pathogenicity test using the same germplasm collections examined for Pi-ta, 65 germplasm collections were resistant and 71 rice germplasm collections were susceptible to isolate IA1 of $M$. oryzae (Fig. 3). Only 5 rice germplasm collections (P881-12-4-B, Ai Chueh Li, 519, SL 22-

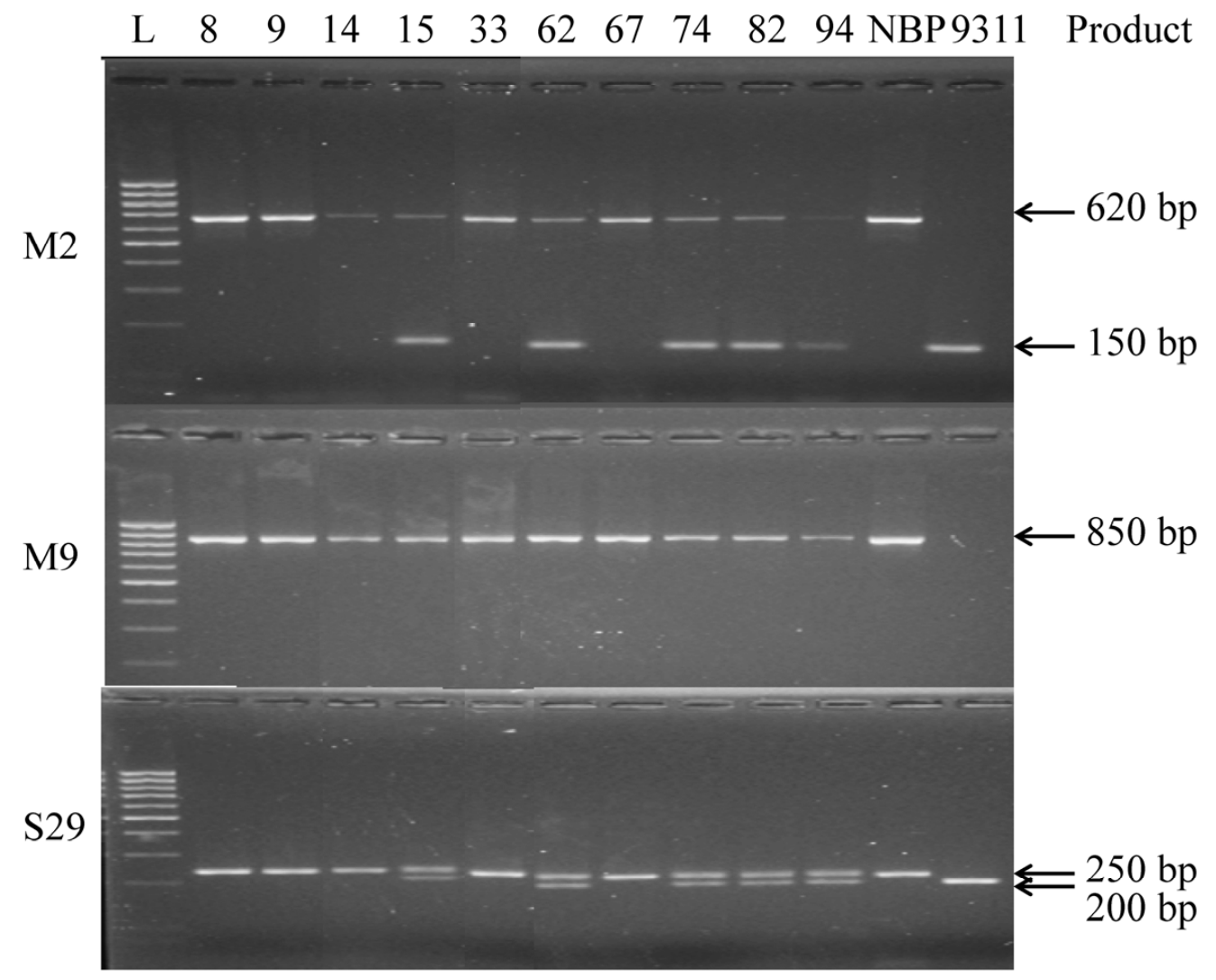

\section{$\begin{array}{llllllllllllll}\text { Disease score } & \text { S3 } & \text { S3 } & \text { S5 } & \text { R0 } & \text { S4 } & \text { R0 } & \text { S4 } & \text { R0 } & \text { R0 } & \text { R0 } & \text { S5 } & \text { R0 }\end{array}$}

Fig. 2. Gel showing polymerase chain reaction (PCR) products with three insertion-deletion (InDel) markers in selected recombinants and parents. Sizes of PCR products amplified with each of InDel markers M2, M9, and S29. Lane L was obtained from the 1-kb-plus DNA ladder; lanes 8 to 94 are recombinants; and Nipponbare (NBP) and 9311 are parents. PCR products were separated on a $3 \%$ agarose gel and stained with 10\% SYBR Safe DNA gel stain.

Table 3. Analysis of blast resistance $(R)$ genes in rice germplasm collections after inoculation with Magnaporthe oryzae isolate IA1

\begin{tabular}{|c|c|c|c|c|c|c|c|c|c|c|}
\hline \multirow[b]{2}{*}{ Accession } & \multirow[b]{2}{*}{ Cultivar } & \multicolumn{3}{|c|}{ InDel markers $^{\mathbf{a}}$} & \multirow[b]{2}{*}{$\mathbf{D R}^{\mathbf{c}}$} & \multicolumn{2}{|c|}{ Predicted $R$ genes ${ }^{b}$} & \multirow[b]{2}{*}{ Gene $^{d}$} & \multirow[b]{2}{*}{ Country } & \multirow[b]{2}{*}{ Region } \\
\hline & & M2 & M9 & S29 & & Pi-ta & $\operatorname{Pi61}(t)$ & & & \\
\hline PI372046 & P881-12-4-B & 150 & 850 & 250 & R 0 & + & + & 2 & Colombia & South America \\
\hline PI244727 & Esperanza & 150 & 850 & 250 & S 5 & + & - & 1 & Cuba & Central America \\
\hline PI392702 & Gazi & 150 & 850 & 250 & R 1 & + & + & 2 & Fiji & South Pacific \\
\hline PI403369 & D 6-2-2 & 150 & 850 & 250 & S 5 & + & - & 1 & India & Subcontinent \\
\hline PI430982 & Shima & 150 & 850 & 250 & S 5 & + & - & 1 & Iraq & Mideast \\
\hline PI403401 & Gaza & 150 & 850 & 250 & S 5 & + & - & 1 & Mozambique & Africa \\
\hline PI431111 & WB 103 & 150 & 850 & 250 & S 5 & + & - & 1 & Pakistan & Subcontinent \\
\hline PI433797 & SL 22-613 & 150 & 850 & 250 & R 0 & + & + & 2 & Sierra Leone & Africa \\
\hline PI276860 & Laat & 150 & 850 & 250 & S 5 & + & - & 1 & Suriname & South America \\
\hline PI389036 & Ai Chueh Li & 150 & 850 & 250 & R 0 & + & + & 2 & Taiwan & China \\
\hline PI400276 & 519 & 150 & 850 & 250 & R 0 & + & + & 2 & Uruguay & South America \\
\hline
\end{tabular}

${ }^{a}$ M2 and S29 were co-dominant insertion-deletion (InDel) markers and flanked the Pi61(t) gene; M9 was a dominant InDel marker and co-segregated with Pi61 $(t)$. Allele sizes of M2, M9, and S29 were 620, 850, and 250 nucleotides (nt), respectively, for Nipponbare; and allele sizes of M2 and S29 were 150 and $220 \mathrm{nt}$, respectively, for 93-11.

${ }^{\mathrm{b}}$ Symbols + and - indicate the presence and absence, respectively of the Pi-ta gene, based on Wang et al. (25), or Pi61(t).

${ }^{\mathrm{c}}$ Disease reaction (DR): 0 to $2=$ resistant $(\mathrm{R})$ and 3 to $5=$ susceptible (S). The isolate for $M$. oryzae was 09S38-227R1-C (IA1).

d Number of $R$ gene. 


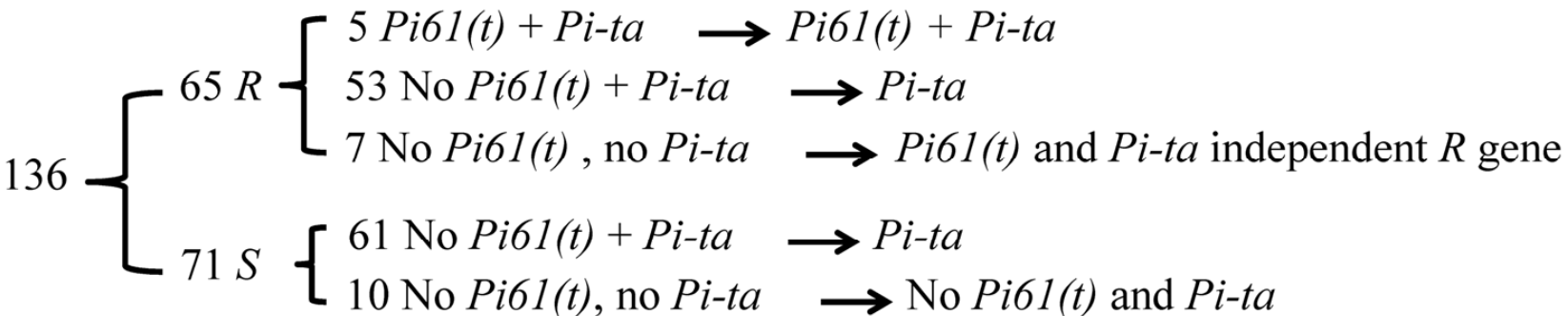

Fig. 3. Analysis of the existence of Pi61(t) and Pi-ta in 136 rice germplasm collections. The diagram shows the germplasm collection number and the results of disease reactions after inoculation with the race (isolate) IA1(09S38-227R1-C) of Magnaporthe oryzae. $R=$ resistant; $S=$ susceptible; + and - indicate the presence and absence, respectively, of Pi61(t) or Pi-ta.

613, and Gazi) from 136 tested germplasm collections contained both Pi61(t) and Pi-ta. This suggests that Pi61(t) and Pi-ta, in these germplasms, may share the same ancestors and can be used as donors for both $R$ genes. DNA markers M2, M9, and S29 co segregated with $P i-61(t)$ could be used for improving blast resistance via MAS

\section{Acknowledgments}

The project was supported, in part, by the U.S. National Science Foundation Plant Genome Research Program Number 0701745. We thank M. Lin, T. Bianco, Y. Liu, and A. Jackson for excellent technical assistance and useful discussions

\section{Literature Cited}

1. Ballini, E., Morel, J. B., Droc, G., Price, A., Courtois, B., Notteghem, J. L., and Tharreau, D. 2008. A genome-wide meta-analysis of rice blast resistance genes and quantitative trait loci provides new insights into partial and complete resistance. Mol. Plant-Microbe Interact. 21:859-868. Online publication. doi:10.1094/MPMI-21-7-0859

2. Costanzo, S., and Jia, Y. 2010. Sequence variation at the rice blast resistance gene Pi-km locus: implications for the development of allele specific markers. Plant Sci. 178:523-530.

3. Deng, Y., Zhu, X., Shen, Y., and He, Z. 2006. Genetic characterization and fine mapping of the blast resistance locus Pigm(t) tightly linked to Pi2 and $P i 9$ in a broad-spectrum resistant Chinese variety. Theor. Appl. Genet. 113:705-713.

4. Falconer, D. S., and Mackay, T. F. C. 1996. Introduction to Quantitative Genetics, 4th ed. Prentice Hall, London.

5. Fjellstrom, R., McClung, A. M., and Shank, A. R. 2006. SSR markers closely linked to the Pi-z locus are useful for selection of blast resistance in a broad array of rice germplasm. Mol. Breed. 17:149-157.

6. Fujita, D., Ebron, L. A., Kobayashi, N., and Fukuta, Y. 2009. DNA marker analysis of blast resistance genes Pib and Pita in IRRI-bred rice varieties comparing with gene estimation by a differential system. In: Advances in Genetics, Genomics and Control of Rice Blast Disease. G. L. Wang and B. Valent, eds. Springer Science+Business Media B.V. Online publication. doi:10.1007/978-1-4020-9500-9 31

7. Hulbert, S. H., and Bennetzen, J. L. 1991. Recombination at the Rp1 locus of maize. Mol. Gen. Genet. 226:377-382.

8. Imbe, T., and Matsumoto, S. 1985. Inheritance of resistance of rice varieties to the blast fungus strains virulent to the variety "Reiho". Jpn. J. Breed. 35:332-339.

9. International Rice Genome Sequencing Project. 2005. The map-based of the rice genome. Nature 436:793-800.

10. Jia, Y., Jia, M. H., Wang, X., and Liu, G. 2012. Indica and Japonica crosses resulting in linkage block and recombination suppression on rice chromosome 12. PLoS ONE 7:e43066. Online publication. doi:10.1371/ journal.pone.0043066

11. Jia, Y., Lee, F. N., and McClung, A. 2009. Determination of resistance spectra of the Pi-ta and Pi-k genes to U.S. races of Magnaporthe oryzae causing rice blast in a recombinant inbred line population. Plant Dis. 93:639-644.

12. Jia, Y., Wang, Z., and Singh, P. 2002. Development of dominant rice blast Pi-ta resistance gene markers. Crop Sci. 42:2145-2149.

13. Kim, J. S., Ahn, S. Nag., Kim, C. K., and Shim, C. K. 2010. Screening of rice blast resistance genes from Aromatic rice germplasms with SNP markers. Plant Pathol. J. 26:70-79.

14. Kiyosawa, S. 1967. Genetic studies on host-pathogen relationship in the rice blast disease. Pages 137-153 in: Proc. Symp. Rice Dis. Control by growing resistant varieties and other measures. Minist. Agric. For. Tokyo.

15. Kobayashi, N., Telebanco-Yanoria, M. J., Tsunematsu, H., Kato, H., Imbe, T., and Fukuta, Y. 2007. Development of new sets of international standard differential varieties for blast resistance in rice (Oryza sativa L.). JARQ Jpn. Agric. Res. Q. 41:31-37.

16. Koide, Y., Telebanco-Yanoria, M. J., Fukuta, Y., and Kobayashi, N. 2013.
Detection of novel blast resistance genes, Pi58(t) and Pi59(t), in a Myanmar rice landrace based on a standard differential system. Mol. Breed. 32:241252. Online publication. doi:10. 1007/s11032-013-9865-5

17. Lei, C., Hao, K., Yang, Y., Ma, J., Wang, S., Wang, J., Cheng, Z., Zhao, S., Zhang, X., Guo, X., Wang, C., and Wan, J. 2013. Identification and fine mapping of two blast resistance genes in rice cultivar 93-11. Crop J. Online publication. doi:10.1016/j.cj.2013.07.007

18. Liu, X., Yang, Q., Lin, F., Hua, L., Wang, C., Wang, L., and Pan, Q. 2007. Identification and fine mapping of $P i 39(t)$, a major gene conferring the broad-spectrum resistance to Magnaporthe oryzae. Mol. Genet. Genomics 278:403-410. Online publication. doi:10.1007/s00438-007-0258-5

19. McCouch, S. R., Teytelman, L., Xu., Y., Lobos, K. B., Clare, K., Walton, M., Fu, B., Maghirang, R., Li, Z., Xing, Y., Zhang, Q., Kono, I., Yano, M., Fjellstrom, R., DeClerck, G., Schneider, D., Cartinhour, S., Ware, D., and Stein, L. 2002. Development and mapping of 2240 new SSR markers for rice (Oryza sativa L.). DNA Res 9:199-207.

20. RoyChowdhury, M., Jia, Y., Jackson, A., Jia, M. H., Fjellstrom, R., and Cartwright, R. D. 2012. Analysis of rice blast resistance gen $P i-z$ in rice germplasm using pathogenicity assays and DNA markers. Euphytica 184:35-46.

21. RoyChowdhury, M., Jia, Y., Jia, M. H., Fjellstrom, R., and Cartwright, R. D. 2012. Identification of the rice blast resistance gene $P i b$ in the National Small Grains Collection. Phytopathology 102:700-706.

22. Sharma, T. R., Rai, A. K., Gupta, S. K., Vijayan, J., Devanna, B. N., and Ray, S. 2012. Rice blast management through host-plant resistance: retrospect and prospects. Agric. Res. 1:37-52.

23. Takehisa, H., Yasuda, M., Fukuta, Y., Kobayashi, N., Hayashi, N., Nakashita, H., Abe, T., and Sato, T. 2009. Genetic analysis of resistance genes in an Indica-type rice (Oryza sativa L.), Kasalath, using DNA markers. Breed. Sci. 59:253-260.

24. Valent, B., Farrall, L., and Chumley, F. G. 1991. Magnaporthe grisea genes for pathogenicity and virulence identified through a series of backcrosses. Genetics 127:87-101.

25. Wang, X., Fjellstrom, R., Jia, Y., Yan, W., Jia, M. H., Scheffler, B. E., Wu, D., Shu, Q., and McClung, A. 2010. Characterization of Pi-ta blast resistance gene in an international rice core collection. Plant Breed. 129:491501.

26. Wang, Z. X., Yano, M., Yamanouchi, U., Iwamoto, M., Monna, L., Hayasaka, H., Katayose, Y., and Sasaki, T. 1999. The Pib gene for rice blast resistance belongs to the nucleotide binding and leucine-rich repeat class of plant disease resistance genes. Plant J. 19:55-64.

27. Xin, Z., Velten, J. P, Oliver, M. J., and Burke, J. J. 2003. High-throughput DNA extraction method suitable for PCR. BioTechniques 34:802-826.

28. Yaegashi, H., Asaga, K., and Yamada, M. 1983. Presumed genotypes for true resistance of recommended rice varieties to rice blast. Bull. Tohoku Nat. Agric. Exp. Stn. 68:1-19.

29. Yang, H., Jia, M. H., Jia, Y., Xing, J., Venu, R. C., Bellizzi, M., Yuan, L., Wang, Z., Sun, C., and Wang, G. 2013. Molecular mapping of four blast resistance genes using recombinant inbred lines of 93-11 and Nipponbare. J. Plant Biol. 56:91-97.

30. Yang, Q., Lin, F., Wang, L., and Pan, Q. 2009. Identification and mapping of Pi41, a major gene conferring resistance to rice blast in Oryza sativa subsp. Indica reference cultivar, 93-11. Theor. Appl. Genet. 118:1027-1034.

31. Yu, J., Hu, S., Wang, J., Wong, G. Ka-Shu., Li, S., Liu, B., Deng, Y., Dai, L., Zhou, Y., Zhang, X., Cao, M., Liu, J., Sun, J., Tang, J., Chen, Y., Huang, X., Lin, W., Ye, C., Tong, W., Cong, L., Geng, J., Han, Y., Li, W., Hu, G., Huang, X., Li, W., Li, J., Liu, Z., Li, L., Liu, J., Qi, Q., Liu, J., Li, L., Li, T. Wang, X., Lu, H., Wu, T., Zhu, M., Ni, P., Han, H., Dong, W., Ren, X., Feng, X., Cui, P., Li, X., Wang, H., Xu, X., Zhai, W., Xu, Z., Zhang, J., He, S., Zhang, J., Xu, J., Zhang, K., Zheng, X., Dong, J., Zeng, W., Tao, L., Ye, J., Tan, J., Ren, X., Chen, X., He, J., Liu, D., Tian, W., Tian, C., Xia, H., Bao, Q., Li, G., Gao, H., Cao, T., Wang, J., Zhao, W., Li, P., Chen, W., Wang, X., Zhang, Y., Hu, J., Wang, J., Liu, S., Yang, J., Zhang, G., Xiong, Y., Li, Z., Mao, L., Zhou, C., Zhu, Z., Chen, R., Hao, B., Zheng, W., Chen, S., Guo, W., Li, G., Liu, S., Tao, M., Wang, J., Zhu, L., Yuan, L., and Yang, H. 2002. A draft sequence of the rice genome (Oryza sativa L. ssp. indica). Science 296:79-92. 